\title{
Relationship between in vitro susceptibility test results and treatment outcomes for gram-positive mastitis pathogens following treatment with cephapirin sodium
}

\author{
M. D. Apparao, ${ }^{\star}$ P. L. Ruegg, ${ }^{* 1}$ A. Lago, $†$ S. Godden, $†$ R. Bey, $†$ and K. Leslie \\ *University of Wisconsin, Madison 53706 \\ †University of Minnesota, St. Paul 55455 \\ ‡University of Guelph, Guelph, Ontario, Canada N1G 2W1
}

\begin{abstract}
The selection of antimicrobial agents for the treatment of mastitis has often been based on results of in vitro susceptibility testing. However, the results of in vitro susceptibility tests have been shown to be poor predictors of treatment outcomes. The objective of this study was to determine if an association existed between results of antimicrobial susceptibility tests and outcomes of mastitis caused by gram-positive pathogens recovered from quarters that received treatment with cephapirin sodium. Mastitis pathogens were obtained from a multi-site clinical trial that evaluated the benefits of using an on-farm culturing system. Target pathogens $(\mathrm{n}=187)$ comprised coagulase-negative staphylocci $(65 \%)$, Streptococcus spp. (14\%), other pathogens $(12 \%)$, and Staphylococcus aureus (11\%), which were recovered from quarters that received treatment using cephapirin sodium. The antimicrobial susceptibility profile to cephapirin was determined using the broth micro-dilution technique. The overall bacteriological cure rate achieved by cephapirin treatment was $82 \%$. Bacteriological outcomes (cure or treatment failure) were not associated with pathogen type. A recurrent case of mastitis was observed in 10 quarters classified as cures and 3 quarters classified as treatment failures. Recurrence of mastitis was not associated with bacteriological outcomes or susceptibility test results. In vitro susceptibility to cephapirin was exhibited by 94.8 and $91.2 \%$ of pathogens recovered from quarters classified as cures and treatment failures, respectively. Bacteriological outcomes of mastitis treated using cephapirin were not associated with in vitro susceptibility test results or in vitro minimum inhibitory concentration values. In this population, there was an $82 \%$ probability of treatment success when the isolate was susceptible but only a $27 \%$ probability of treatment failure when the isolate
\end{abstract}

Received September 8, 2008.

Accepted February 11, 2009.

${ }^{1}$ Corresponding author: plruegg@wisc.edu was resistant. Based on this research, results of in vitro susceptibility tests should not be used as the primary guide for treatment decisions regarding intramammary cephapirin sodium.

Key words: mastitis, antimicrobial, susceptibility, resistance

\section{INTRODUCTION}

Bovine mastitis is responsible for great economic losses to the worldwide dairy industry and accounts for the single largest usage of antimicrobial agents in dairy cattle (USDA, 2005). Pol and Ruegg (2007) reported that more than two-thirds of antimicrobials used for treatment of mastitis were administered via intramammary infusion, whereas the remainder were administered parentally. In conventional US dairy herds, cephapirin, pirlimycin, amoxicillin, cloxacillin, erythromycin, penicillin, tetracycline, ceftiofur, ampicillin, and sulfonamides are commonly used for the treatment of mastitis (Pol and Ruegg, 2007).

Efficacy of antimicrobial treatment depends on inherent characteristics of the pathogen, duration of treatment, host factors, and the concentration of the drug that can be maintained at the site of infection (Constable and Morin, 2003). Selection of an appropriate antimicrobial for treatment of mastitis is often based on interpretation of categorical results (susceptible, intermediate, or resistant) obtained from in vitro susceptibility tests or quantitative results obtained from in vitro tests that determine MIC (Constable and Morin, 2003). For several antimicrobials, outcomes of these in vitro tests have not been shown to be reliable predictors of treatment outcomes (Sandholm et al., 1990; Owens et al., 1997; Cattell et al., 2001; Constable and Morin, 2002; Hoe and Ruegg, 2005; Apparao et al., 2009).

Cephapirin sodium is a bactericidal antimicrobial that belongs to the first-generation cephalosporin class of antimicrobials and is frequently used for treatment of mastitis. Like many other intramammary antimicrobials, cephapirin was approved before the FDA required 
manufacturers to provide data to determine specific breakpoints for veterinary pathogens. The objective of this study was to determine if results of in vitro antimicrobial susceptibility testing of mastitis pathogens were associated with bacteriologic cure following intramammary administration of cephapirin sodium.

\section{MATERIALS AND METHODS}

\section{Enrollment, Sampling, and Treatment}

Isolates for this study were obtained from cases that were enrolled in a multi-site field study that had a primary objective of evaluating use of on-farm culture systems to direct treatment of either clinical or subclinical mastitis (Lago et al., 2006). Participating herds were located in Wisconsin, Minnesota, or Ontario. To maximize protocol compliance, herds participated in either the clinical mastitis trial or subclinical mastitis trial (no herds enrolled both types of cases).

Enrollment of Cases. Cattle that exhibited systemic signs of disease or any condition requiring systemic treatment with antibiotics were not eligible for enrollment. Clinical mastitis cases were enrolled throughout lactation when farm personnel from herds participating in the clinical mastitis trial $(\mathrm{n}=8)$ observed visually abnormal milk. Cows $(\mathrm{n}=396 ; 455$ quarters $)$ that experienced clinical mastitis were enrolled between June 2005 and May 2007.

Trained farm personnel from herds participating in the subclinical mastitis trial $(\mathrm{n}=16)$ screened all postparturient cows for subclinical mastitis within $24 \mathrm{~h}$ of calving using the California Mastitis Test. Subclinical mastitis cases were defined as visually normal milk with California Mastitis Test score $>0$ (scale: $0=$ no gel or thickening; $1=$ slight or mild thickening; $2=$ moderately thick gel; $3=$ very thick gel). Cows $(\mathrm{n}=1,881$; 7,835 quarters) that experienced subclinical mastitis were enrolled between May 2005 and August 2006.

Sampling. Sampling schedules were identical for cases of clinical and subclinical mastitis. Aseptic, duplicate quarter milk samples were collected at enrollment, before administration of treatment, and approximately $14 \mathrm{~d}(13-16 \mathrm{~d})$ and $21 \mathrm{~d}(20-24 \mathrm{~d})$ after treatment was concluded. Milk samples were stored in an on-farm freezer until they were transported to laboratories for initial microbiological examination.

Data Used in this Study. The methodology used for randomization and assignment of treatments for the original study has been described previously (Lago et al., 2006). Of animals enrolled in the original study, only quarters that were infected with a gram-positive pathogen and received intramammary treatment with cephapirin sodium were eligible for this study. Data ob- tained from cows were excluded when 1) quarters were infected with gram-negative pathogens, 2) quarters had more than one pathogen type isolated, 3) quarters did not receive the labeled treatment of cephapirin, and 4) quarters received additional treatments.

\section{Laboratory Procedures}

Identification of Pathogens. Depending on herd, initial microbiological examination was performed at laboratories at the University of Minnesota (clinical, $\mathrm{n}$ $=194$ samples; subclinical, $\mathrm{n}=5,360$ samples), University of Wisconsin (clinical, $\mathrm{n}=236$ samples), or University of Guelph (clinical, $\mathrm{n}=25$ samples; subclinical, $\mathrm{n}=$ 2,475 samples). Microbiological procedures for the initial identification of bacteria were standardized among laboratories and performed in accordance to guidelines of the National Mastitis Council (NMC, 1999). Briefly, $0.01 \mathrm{~mL}$ of milk was streaked on blood agar plates and incubated at $36^{\circ} \mathrm{C}$ for $24 \mathrm{~h}$. An intramammary infection was defined as the isolation of 1 or 2 pathogens from a single quarter milk sample. Samples from which 3 or more pathogens were isolated were classified as contaminated. When an original milk sample was contaminated, the duplicate sample was used for culture. Pathogens were further differentiated based on Gram stain characteristics, colony morphology, and results of catalase and coagulase tests. Catalase-negative, grampositive pathogens were classified as Streptococcus spp. and were further differentiated based on the Christie, Atkins, Munch-Petersen (CAMP) test and growth on esculin medium. All eligible Staphylococcus and Streptococcus were frozen and stored at $-70^{\circ} \mathrm{C}$ until they were sent to a central laboratory (University of Wisconsin) for speciation and antimicrobial susceptibility testing. Bacterial species of CNS and Streptococcus spp. were determined using the appropriate API system (bioMerieux, Durham, NC) with a confidence level of $\geq 75 \%$.

Antimicrobial Susceptibility Testing. The MIC of all gram-positive pathogens were determined using a broth micro-dilution method (Sensititer, Trek Diagnostics, Westlake, OH). This method adheres to the guidelines established by the Clinical Laboratory Standards Institute (CLSI; CLSI, 2007). Each 96-well custom-designed extended dilution panel for MIC determination contained serial double dilutions of the following 12 antimicrobial agents: ampicillin $(0.015-8.0 \mu \mathrm{g} /$ $\mathrm{mL})$, ceftiofur $(0.015-4.0 \mu \mathrm{g} / \mathrm{mL})$, cephalothin $(0.03-16$ $\mu \mathrm{g} / \mathrm{mL})$, enrofloxacin $(0.03-2.0 \mu \mathrm{g} / \mathrm{mL})$, erythromycin (0.015-4.0 $\mu \mathrm{g} / \mathrm{mL})$, oxacillin $(0.12-4.0 \mu \mathrm{g} / \mathrm{mL})$, penicillin $(0.015-8.0 \mu \mathrm{g} / \mathrm{mL})$, penicillin/novobiocin $(0.06-8.0$ $\mu \mathrm{g} / \mathrm{mL})$, pirlimycin $(0.06-8.0 \mu \mathrm{g} / \mathrm{mL})$, sulfadimethoxine $(16-256 \mu \mathrm{g} / \mathrm{mL})$, spiramycin $(1-16 \mu \mathrm{g} / \mathrm{mL})$, and 
tetracycline $(0.06-8.0 \mu \mathrm{g} / \mathrm{mL})$. A positive control well was included in each panel.

Isolates were grown twice on blood agar, and bacterial suspensions were prepared and standardized to a 0.5 McFarland standard using a nephelometer (Sensititer, Trek Diagnostics, Westlake, $\mathrm{OH}$ ) per the manufacturer's instructions. Aliquots $(50 \mu \mathrm{L})$ of this suspension were dispensed into each well and the plates were incubated aerobically at $36^{\circ} \mathrm{C}$ for 18 to $24 \mathrm{~h}$. In vitro MIC values for the various pathogens tested were captured electronically and transferred to a database for data analysis. Quality control tests were performed [in accordance to the guidelines specified by the CLSI (2007)] using American Type Culture Collection (ATCC) strains: Staphylococcus aureus ATCC 29213 and Enterococcus faecalis ATCC 29212 (CLSI, 2007).

\section{Definitions}

Depending on bacteriological outcome after therapy, quarters were classified as either treatment failures or cures. A treatment failure was defined as recovery of the same bacterial species from the pretreatment milk sample and at least one of the posttreatment milk samples. A cure was defined as the absence of bacteria (or recovery of different bacterial species) in both posttreatment milk samples compared with the pretreatment milk sample. A recurrence of mastitis in a quarter was defined as an occurrence of clinical mastitis in the same quarter within 8 to $60 \mathrm{~d}$ of receiving treatment with cephapirin sodium (regardless of microbiological outcome). Resistance was defined using CLSI (2007) breakpoints: $\leq 8 \mu \mathrm{g} / \mathrm{mL}$ (susceptible), $16 \mu \mathrm{g} / \mathrm{mL}$ (intermediate), and $>32 \mu \mathrm{g} / \mathrm{mL}$ (resistant).

\section{Statistical Analysis}

Statistical analysis was performed using SAS version 9.1 (SAS Institute Inc., Cary, NC). The MIC data for cephalothin were summarized by calculating the 50th $\left(\mathrm{MIC}_{50}\right)$ and 90th $\left(\mathrm{MIC}_{90}\right)$ percentiles, as well the proportion of isolates susceptible, intermediate, or resistant. The percentage of isolates that were inhibited at each concentration of cephalothin was also calculated.

PROC LIFETEST (SAS Institute) was used to perform survival analysis of isolates based on category of treatment outcome (cure or treatment failure). For the Kaplan-Meier survival curves, time was defined as cephalothin concentration in wells and event was defined as inhibition of bacterial growth. Isolates that were not inhibited at the highest concentration were right censored. Log rank and Wilcoxon tests were used to test the null hypothesis of no difference in the survival functions (inhibitory concentration of cephalothin) among strata (cure or treatment failures). The statistical level of significance was set at $P<0.05$.

The relationship between results of in vitro susceptibility testing and bacteriological outcomes was examined using a logistic regression model (PROC LOGISTIC; SAS Institute). The full logistic regression model was as follows: bacteriological outcome (treatment failure, cure $)=$ cephalothin resistance (yes, no) + case type (clinical, subclinical) + parity (parity 1, parity $>1)+$ pathogen type (CNS, Streptococcus spp., Staph. aureus, other) + random error.

\section{RESULTS}

\section{Clinical Mastitis}

Of cows enrolled in the original study, 396 cows (455 quarters) were initially diagnosed with clinical mastitis. Of these, only 50 cows (51 quarters) met the criteria for inclusion in the present study. Quarters were excluded because of no growth $(\mathrm{n}=145)$, growth of gram-negative pathogens $(\mathrm{n}=140)$, growth of other pathogens ( $\mathrm{n}$ $=56)$, contaminated samples $(\mathrm{n}=10)$, quarters from which 2 pathogens were recovered $(\mathrm{n}=40)$, quarters that received additional treatments $(\mathrm{n}=20)$, and missing samples $(\mathrm{n}=44)$. Clinical mastitis cases were caused by Streptococcus spp. $(\mathrm{n}=19)$, CNS $(\mathrm{n}=15)$, Staph. aureus $(\mathrm{n}=9)$, and other gram-positive bacteria $(\mathrm{n}=8$; Table 1$)$.

Treatment resulted in a bacteriological cure rate of $84 \%$ (Table 1). Of clinical quarters that were categorized as bacteriological cures $(\mathrm{n}=43), 5(12 \%)$ were infected with a pathogen that demonstrated in vitro resistance to cephapirin (Table 2). Similarly, of quarters $(\mathrm{n}=8)$ that were considered to be treatment failures, 1 (12\%) was infected with a pathogen (Enterococcus faecium) that demonstrated in vitro resistance to cephapirin (Table 2).

Of quarters $(n=7)$ that had a recurrent case of mastitis between 8 and $60 \mathrm{~d}$ after receiving treatment, 5 cases occurred in quarters defined as cured of infection and 2 cases occurred in quarters defined as treatment failures. In all recurrent mastitis quarters, the pathogens isolated from the initial case demonstrated in vitro susceptibility to cephapirin (Table 2).

Homogeneous survival curves were observed for pathogens that were classified as cures $(\mathrm{n}=43)$ and treatment failures $(\mathrm{n}=8$; log rank, $P>0.56$; Wilcoxon, $P>0.40)$ indicating that the inhibitory concentrations of cephalothin were not different for quarters categorized as cured or treatment failures (data not shown).

\section{Periparturient Subclinical Mastitis}

Of 1,881 cows $(7,835$ quarters) initially enrolled in the subclinical mastitis trial, only 100 cows (136 quar- 
Table 1. Proportion of cases and bacteriological cure rates by pathogen

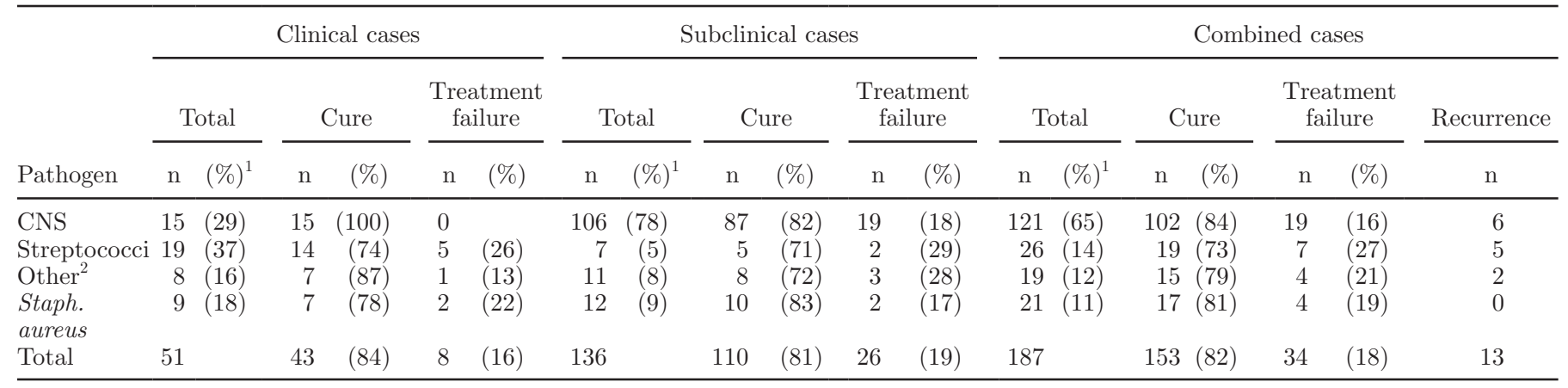

${ }^{1}$ Proportion of isolates enrolled in this study; case type was associated with pathogen $\left(\chi^{2}=45.6\right.$; df $\left.=3 ; P<0.001\right)$.

${ }^{2}$ Other includes pathogens belonging to the genera Aerococcus spp., Enterococcus spp., Kokuria spp., and Micrococcus spp.

ters) met the criteria for inclusion in the present study. Quarters were excluded because of no growth ( $\mathrm{n}=$ $4,230)$, growth of gram-negative pathogens $(\mathrm{n}=280)$, growth of more than one type of pathogen $(\mathrm{n}=1,560)$, growth of other pathogens $(\mathrm{n}=884)$, contaminated samples $(\mathrm{n}=185)$, quarters that received additional treatments $(\mathrm{n}=186)$, and missing data or isolates ( $\mathrm{n}$ $=510)$. Subclinical infections $(\mathrm{n}=136)$ were caused by CNS $(\mathrm{n}=106)$, Staph. aureus $(\mathrm{n}=12)$, other grampositive pathogens $(\mathrm{n}=11)$, and Streptococcus spp. (n $=7)$.

Treatment with cephapirin sodium in subclinical quarters resulted in a bacteriological cure rate of $81 \%$ (Table 1). Among cured quarters $(\mathrm{n}=110), 4(4 \%)$ pathogens demonstrated in vitro resistance to cephapirin, and among quarters that were treatment failures $(\mathrm{n}=26), 1$ isolate each was intermediate or resistant (combined $\mathrm{n}=2 ; 8 \%$; Table 2 ).
A subsequent occurrence of a clinical mastitis event in the same quarter within 8 to $60 \mathrm{~d}$ of the subclinical event was recorded in 6 (4\%) quarters. For consistency, these cases were defined as "recurrences." All 6 cases occurred in quarters previously defined as bacteriological cured infection, and all pathogens isolated from the initial subclinical episode demonstrated in vitro susceptibility to cephapirin (Table 2).

Homogeneous survival curves were observed for pathogens that were classified as cures $(\mathrm{n}=110)$ and treatment failures $(\mathrm{n}=26$; $\log$ rank, $P>0.42$; Wilcoxon, $P>0.61$; data not shown).

\section{Combined Clinical and Subclinical Data}

Homogeneous survival curves were observed for both clinical and subclinical infections, and no difference was found in the cure rates of clinical and subclinical

Table 2. Treatment outcomes by results of susceptibility testing and case type ${ }^{1}$

\begin{tabular}{|c|c|c|c|c|c|c|c|}
\hline \multirow{2}{*}{$\begin{array}{l}\text { In vitro susceptibility test } \\
\text { results for cephalothin }{ }^{2}\end{array}$} & \multirow[b]{2}{*}{ Total } & \multicolumn{2}{|c|}{ Cured } & \multicolumn{2}{|c|}{ Treatment failure } & \multicolumn{2}{|c|}{ Recurrence $^{3}$} \\
\hline & & $\mathrm{n}$ & $(\%)$ & $\mathrm{n}$ & $(\%)$ & $\mathrm{n}$ & $(\%)$ \\
\hline \multicolumn{8}{|l|}{ Clinical cases } \\
\hline Susceptible & 46 & 39 & $(84)$ & 7 & $(16)$ & 7 & $(16)$ \\
\hline Resistant & 4 & 3 & $(83)$ & 1 & $(17)$ & 0 & \\
\hline Intermediate $^{4}$ & 1 & 1 & & 0 & & & \\
\hline Total & 51 & 43 & $(84)$ & 8 & $(16)$ & 7 & $(14)$ \\
\hline \multicolumn{8}{|l|}{ Subclinical cases } \\
\hline Susceptible & 130 & 106 & $(82)$ & 24 & (18) & 6 & $(5)$ \\
\hline Resistant & 5 & 4 & $(67)$ & 1 & $(33)$ & 0 & \\
\hline Intermediate $^{4}$ & 1 & 0 & & 1 & & & \\
\hline Total & 136 & 110 & $(81)$ & 26 & $(19)$ & 6 & (4) \\
\hline \multicolumn{8}{|l|}{ Combined cases } \\
\hline Susceptible & 176 & 145 & $(82)$ & 31 & $(18)$ & 13 & $(7)$ \\
\hline Resistant & 9 & 7 & $(75)$ & 2 & $(25)$ & 0 & \\
\hline Intermediate $^{4}$ & 2 & 1 & & 1 & & & \\
\hline Total & 187 & 153 & $(82)$ & 34 & $(18)$ & 13 & $(7)$ \\
\hline
\end{tabular}

${ }^{1}$ Bacteriological outcomes were not associated with results of susceptibility testing for cephapirin for combined data $(P=0.53)$.

${ }^{2}$ Cephalothin is used as the class representative of all first generation cephalosporins for in vitro susceptibility testing.

${ }^{3}$ Occurrence of a clinical case 8 to $60 \mathrm{~d}$ after enrollment in the study.

${ }^{4}$ Isolates with intermediate susceptibility test results were combined with resistant for calculation of cure rates. 


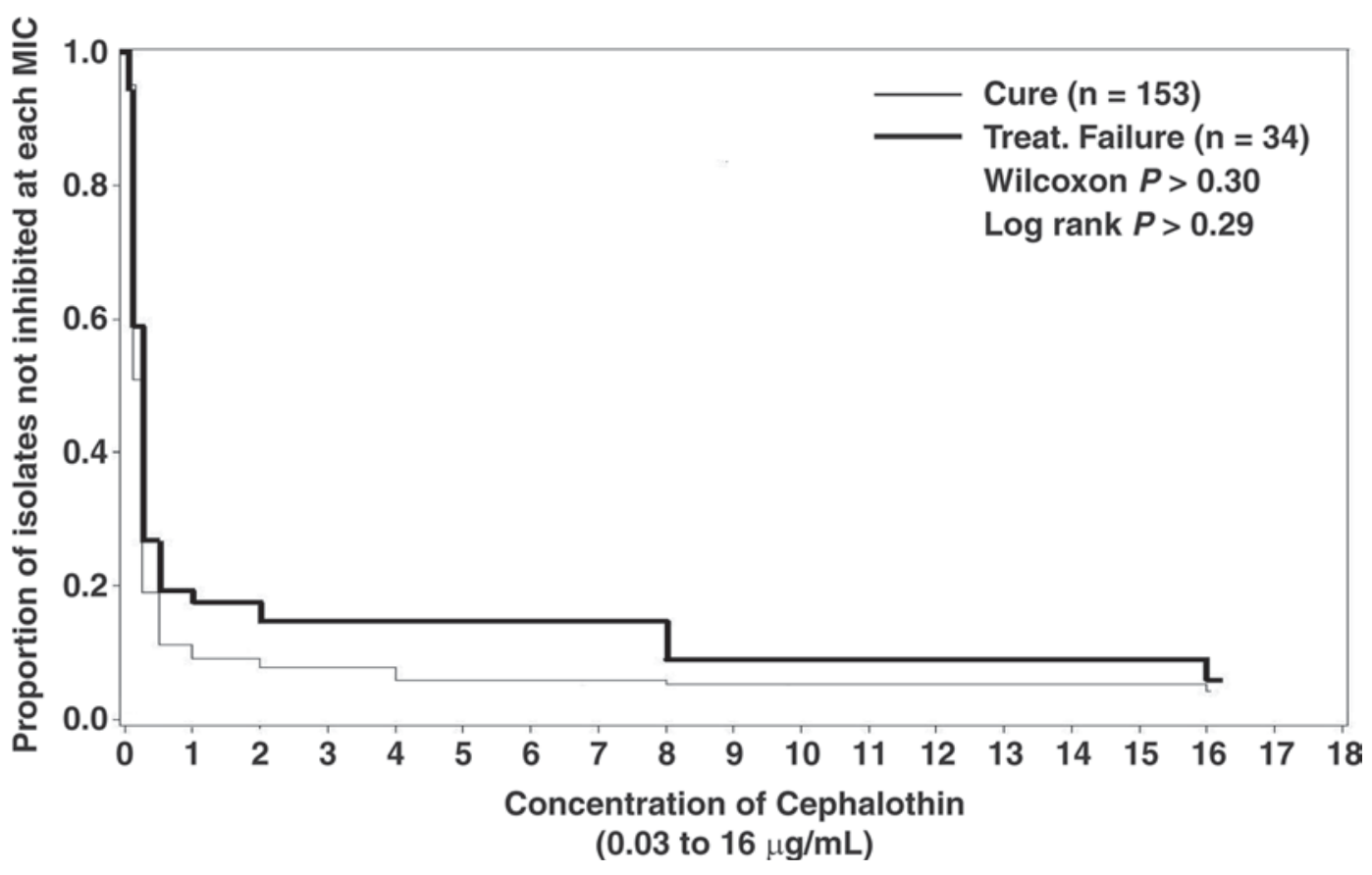

Figure 1. Kaplan-Meier survival curves of clinical and subclinical mastitis pathogens $(\mathrm{n}=187)$ by treatment outcomes to cephapirin.

mastitis. No difference was observed between case types in the proportion of resistant pathogens, so the 2 data sets were combined for further analysis.

The combined data set consisted of quarters infected with gram-positive pathogens categorized as bacteriological cures $(\mathrm{n}=153 ; 82 \%)$ or treatment failures $(\mathrm{n}=$ 34; 18\%; Table 1). Bacteriological outcomes were not associated with pathogen type $\left(\chi^{2} 2.42, P=0.48\right)$. Bacteriological outcomes were not associated with results of in vitro susceptibility testing $\left(\chi^{2}=0.37, P=0.53\right)$. Of pathogens recovered from quarters that were classified as bacteriological cures, $145(94.7 \%)$ demonstrated in vitro susceptibility and $8(5.2 \%)$ demonstrated in vitro resistance to cephapirin (Table 2). Likewise, of gram-positive pathogens recovered from quarters that were classified as treatment failures, 31 (91.1\%) demonstrated in vitro susceptibility and $3(8.9 \%)$ were not susceptible ( $\mathrm{n}=2$ resistant and 1 intermediate) to cephapirin.

The predictive value of a positive test (defined as the probability of bacteriological cure when the in vitro test result indicted that the isolate was susceptible) was $82.4 \%(145 / 176)$. The predictive value of a negative test (defined as the probability of treatment failure when the in vitro test result indicated that the isolate was resistant) was only $27.2 \%(3 / 11)$.

Recurrence of mastitis was not associated with bacteriological outcomes $\left(\chi^{2}=0.06, P=0.79\right)$; recurrence was observed in 13 quarters. Of cured quarters, recurrence occurred in $10(6.5 \%)$ whereas, of treatment failures, recurrence was observed in 3 (8.8\%). Homogeneous survival curves were observed for pathogens that were classified as cures or treatment failures (log rank, $P>0.29$; Wilcoxon, $P>0.30$; Figure 1) indicating that MIC was not associated with bacteriological outcome.

Overall, most isolates tested were susceptible to cephapirin, and very few CNS ( $\mathrm{n}=2$ isolates), Streptococcus spp. ( $\mathrm{n}=1$ isolate), and Staph. aureus ( $\mathrm{n}=$ 1 isolate) exhibited in vitro resistance (Table 3). For CNS, the overall $\mathrm{MIC}_{50}$ was $0.25 \mu \mathrm{g} / \mathrm{mL}$, and the $\mathrm{MIC}_{50}$ for the clinical and subclinical isolates were $0.25 \mu \mathrm{g} / \mathrm{mL}$ (Table 3). The overall $\mathrm{MIC}_{90}$ was $0.5 \mu \mathrm{g} / \mathrm{mL}$ and the $\mathrm{MIC}_{90}$ for subclinical isolates was $0.5 \mu \mathrm{g} / \mathrm{mL}$, whereas the $\mathrm{MIC}_{90}$ for clinical isolates was 8 times greater (4.0 $\mu \mathrm{g} / \mathrm{mL}$; Table 3 ).

For Streptococcus spp. the overall $\mathrm{MIC}_{50}$ was $0.12 \mu \mathrm{g} /$ $\mathrm{mL}$ and the $\mathrm{MIC}_{50}$ for subclinical and clinical isolates were both $0.12 \mu \mathrm{g} / \mathrm{mL}$ (Table 3 ). The overall $\mathrm{MIC}_{90}$ was $4.0 \mu \mathrm{g} / \mathrm{mL}$ and the $\mathrm{MIC}_{90}$ for clinical isolates was $2.0 \mu \mathrm{g} / \mathrm{mL}$, whereas the $\mathrm{MIC}_{90}$ for subclinical isolates was 4 times greater $(8.0 \mu \mathrm{g} / \mathrm{mL}$; Table 3$)$.

For Staph. aureus the overall $\mathrm{MIC}_{50}$ was $0.12 \mu \mathrm{g} / \mathrm{mL}$ and $\mathrm{MIC}_{50}$ for subclinical and clinical isolates were also the same $(0.12 \mu \mathrm{g} / \mathrm{mL}$; Table 3$)$. The overall $\mathrm{MIC}_{90}$ was $0.25 \mu \mathrm{g} / \mathrm{mL}$ and the $\mathrm{MIC}_{90}$ for subclinical and clinical isolates were the same $(0.25 \mu \mathrm{g} / \mathrm{mL}$; Table 3$)$.

Among other pathogens the overall $\mathrm{MIC}_{50}$ was $1.0 \mu \mathrm{g} /$ $\mathrm{mL}$ and the $\mathrm{MIC}_{50}$ for subclinical and clinical isolates 
Table 3. In vitro susceptibility to cephalothin ${ }^{1}$ and MIC distributions for target pathogens isolated from cases of clinical and subclinical mastitis (breakpoint for resistance is $>32 \mu \mathrm{g} / \mathrm{mL}$ )

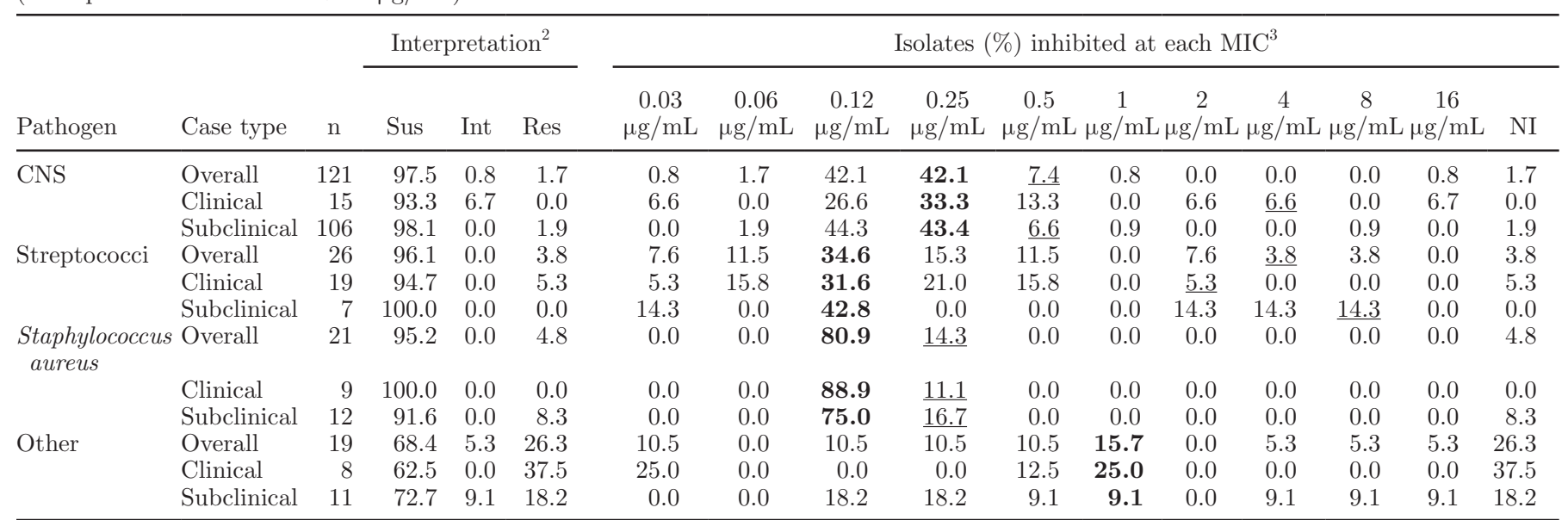

${ }^{1}$ Cephalothin is used as the class representative for all first-generation cephalosporins for in vitro susceptibility testing.

${ }^{2}$ Sus = proportion of pathogens classified as susceptible based on Clinical Laboratory Standards Institute (CLSI) breakpoints; Int = proportion of pathogens classified as intermediate based on CLSI breakpoints; Res = proportion of pathogens classified as resistant based on the CLSI breakpoints.

${ }^{3}$ Bold font indicates the cephalothin concentration that inhibits growth of $50 \%$ of the pathogens $\left(\mathrm{MIC}_{50}\right)$; underlining indicates the cephalothin concentration that inhibits growth of $90 \%$ of the pathogens $\left(\mathrm{MIC}_{90}\right)$; NI = proportion of pathogens in which growth inhibition was not achieved by the greatest concentration tested.

were identical $(1.0 \mu \mathrm{g} / \mathrm{mL}$; Table 3$)$. The overall $\mathrm{MIC}_{90}$ and the $\mathrm{MIC}_{90}$ for clinical and subclinical isolates could not be calculated because greater than $10 \%$ of these isolates were not inhibited at the greatest concentration tested (Table 3).

\section{DISCUSSION}

The objective of the clinical trial (Lago et al., 2006) that generated the collection of microorganisms used in the current study was to evaluate the use of on-farm culturing systems to guide farmers about treatment of mastitis. Cephapirin was selected as the treatment because of its widespread use in the dairy industry, as well as the antimicrobial activity of cephapirin against common gram-positive mastitis pathogens.

The objective of the current study was to identify the relationship between results of in vitro susceptibility testing and clinical outcomes following antimicrobial treatment according to the product label. Therefore, only gram-positive pathogens that were isolated from quarters that received treatment were included in this study. Cephapirin sodium is one of the most frequently used antimicrobials for treatment of mastitis (Sundlof et al., 1995; Pol and Ruegg, 2007). Like most bactericidal $\beta$-lactam antibiotics, the mechanism of cephapirin is concentration-independent; therefore, bacteria are killed to the same extent as long as the concentration exceeds the MIC. However, these antimicrobials are more effective when concentrations above the MIC are maintained for a greater proportion of the inter-dosing interval. Intramammary administration of cephapirin sodium $(200 \mathrm{mg})$ has been reported to result in antimicrobial concentrations in milk ranging from 21 to 280 $\mu \mathrm{g} / \mathrm{mL}$ for 8 to $12 \mathrm{~h}$ in cows with mastitis (Owens et al., 1990). It is hypothetically possible that the concentration of cephapirin in glandular secretions of cows in the present study exceeded the presumed antimicrobial breakpoint for susceptibility $(\leq 8 \mu \mathrm{g} / \mathrm{mL})$ for the duration of treatment.

The bacteriological cure rates for clinical mastitis (84\%), subclinical mastitis (81\%), and combined (82\%) were greater than previously reported by other researchers that employed cephapirin sodium for therapy of IMI (Timms and Schultz, 1984; Daley et al., 1992; Guterbock et al., 1993; Rosenberg et al., 2002). Timms and Schultz (1984) reported bacteriological cures of $23 \%$ (subclinical, $\mathrm{n}=30$ ) and $22 \%$ (clinical, $\mathrm{n}=37$ ) for mastitis cases treated with cephapirin sodium. The most frequently isolated pathogens from subclinical cases were CNS $(n=12)$ and from clinical cases were Micrococcus sp. $(\mathrm{n}=11)$. The reported cure rates in that study may have been influenced by small sample size, large prevalence of minor pathogens, usage of single quarter samples to define mastitis cases, failure to speciate pathogens, and the definition of cures at the genus level.

Daley et al. (1992) compared adjunct therapy with recombinant bovine interleukin-2 to results of intramammary treatment using cephapirin sodium in 36 
cows that were experimentally challenged with intramammary Staph. aureus. This study defined a response to therapy as the absence of Staph. aureus in the milk sample collected immediately after therapy, and a cure as the absence of Staph. aureus in all 14 consecutive daily milk samples collected after therapy. Based on these definitions, a response to therapy ranging from 85 to $100 \%$ and cure ranging from 23 to $55 \%$ for quarters treated with cephapirin was reported. The lower cure rate demonstrated by Daley et al., (1992) as compared with the current study is likely to be due to the rigorous definition of cure (multiple samplings) that they employed. However, the response to therapy that they reported was similar to the cure rates we observed.

Guterbock et al. (1993) compared clinical and bacteriological cure rates of quarter cases of mild clinical mastitis that were randomized to receive treatments of intramammary amoxicillin $(\mathrm{n}=74)$, cephapirin $(\mathrm{n}=$ $75)$, or intramuscular oxytocin $(\mathrm{n}=105)$. Bacteriological cure rates were defined as the absence of the causative pathogen from milk samples obtained immediately after treatment and $21 \mathrm{~d}$ posttreatment. The overall bacteriological cure rates were $43.9,49.1$, and $55.0 \%$ for quarters receiving amoxicillin, oxytocin, or cephapirin, respectively. Bacteriological cures of mastitis caused by Streptococcus spp. that were treated with cephapirin were identical $(73 \%)$ to the cure rate observed in the current study. However, they observed lower bacteriological cure rates for other pathogens groups.

In a recent single-herd study, Rosenberg et al. (2002) reported an overall cure rate of $53 \%$ for cases of subclinical IMI treated using intramammary cephapirin sodium within $2 \mathrm{~d}$ postpartum. The lower cure rate compared with the current study may be attributed to the failure to speciate CNS and Streptococcus spp., as well as the definition of cures at the genus level instead of the species level, as was done in the current trial. Furthermore, the low recurrence rate of mastitis observed for both clinical and subclinical cases classified as cures in the current study strongly suggests that the bacteriological cure rate observed was indeed real, and not an overestimation.

Very few isolates demonstrated in vitro resistance to first-generation cephalosporins. This finding is expected for this class of antimicrobials. Similar findings have been reported by other studies (Erskine et al., 2002; Makovec and Ruegg, 2003; Pol and Ruegg, 2007). For any diagnostic test, when the prevalence of an outcome is minimal, the predictive value of a positive test (probability that the outcome will occur when the test is positive) will be limited (Martin et al., 1987). As expected, few resistant isolates were found and this limited the power of the study to detect a difference. The overall bacteriological cure rates were 77 and $82 \%$ for resistant (not including intermediate) and susceptible isolates, respectively. Using standard power calculations, to achieve a power of $80 \%$ would require a minimum of 805 resistant and 805 susceptible cases. To reach statistical significance, with an expected prevalence of resistance of about $6 \%$, almost 14,000 cases of mastitis would need to be enrolled. On a practical basis, these data indicate that veterinary practitioners would not obtain much useful information from most tests that they performed. For example, if 100 susceptibility tests were performed on gram-positive pathogens, only 6 should be expected to show resistance and of those 6 , only about 1 case $(27 \%)$ would be expected to result in treatment failure.

The current study demonstrated that results of in vitro susceptibility testing based on breakpoints recommended by the CLSI were not able to sufficiently predict bacteriological outcomes after cephapirin therapy. The methodology employed by the CLSI to categorize mastitis pathogens based on in vitro susceptibility may have some inherent deficiencies that might contribute to the poor correlation observed between in vitro susceptibility results and treatment outcomes of mastitis. Pathogens are categorized based on in vitro breakpoints as defined by an expert panel (CLSI, 2007). A breakpoint is a specific MIC selected to predict clinical outcome for a specific pathogen, in a specific disease, in a specific species, given a specific regimen (dose, route, duration, frequency; CLSI, 2007). Antimicrobial susceptibility of mastitis pathogens is often determined using the KirbyBauer disk diffusion method, and breakpoints (often derived from human data) are used to categorize mastitis pathogens as susceptible, intermediate, or resistant to each antimicrobial that is tested.

The reference method for testing mastitis pathogens is the CLSI document M31-A3 (CLSI, 2007), which contains mastitis-specific breakpoints for only 3 antimicrobial agents, (ceftiofur, pirlimycin, and penicillinnovobiocin). When defined by breakpoints set using pharmacokinetic data, the classification (susceptible, intermediate, or resistant) will have a context-dependent validity. The term will only be relevant to therapies sufficiently similar to the form from which the initial pharmacokinetic data was collected.

Most breakpoints used to categorize veterinary pathogens as susceptible or resistant are derived from data on pathogens recovered from infectious conditions in humans and on the pharmacokinetics of drugs in human serum. The validity of applying these breakpoints to the treatment of cattle with mastitis has not been established. This process may be questionable because the $\mathrm{pH}$, electrolyte, fat, protein, and leukocyte concentrations, and growth factor composition of bovine milk are different from those for human plasma (Owens and 
Watts, 1987; Sandholm et al., 1990; Watts and Yancey, 1994; Constable and Morin, 2003).

Breakpoints that have not been validated in cattle may be inaccurate because dosages are different, the pharmacokinetics for these drugs varies in different host animals, and the pathogens are often different from those in humans. Most breakpoints used for antimicrobial agents in human microbiology are based on concentrations of the drug attained in the blood of average patients with usual dosage of the drug. It is however recognized that the concentration of the drug in infected tissues may not be same as in blood. It is also accepted that the concentrations attained in different individuals may vary significantly (Thornsberry et al., 1993). There are a few antimicrobial agents used for human infections for which break points are based solely on levels in urine. This situation can be considered reasonably analogous to that which exists in the therapy of bovine mastitis. The antimicrobial agents used in the treatment of mastitis are frequently infused directly into the individual quarters of the udder. This results in concentrations of the drug in milk that are dose-dependent. However, the drug will be subjected to removal during the milking process, which could result in drug concentrations in milk that are unrelated to the concentration in blood (Thornsberry et al., 1993).

Another concern is that the sensitivity determinations are carried out on nutrient-rich artificial media. Therefore, the data derived may not reflect the in vivo environment (Sandholm et al., 1990). Rapidly multiplying bacteria growing in the test medium are sensitive to antimicrobials, whereas the multiplication rates of mastitis pathogens that are growing in milk may be slower (Sandholm et al., 1990).

The current study was designed to utilize customdesigned extended antimicrobial dilution panels to assess the relationship between MIC values (regardless of breakpoint) and treatment outcomes. However, the Kaplan-Meier survival curves (as indicated in Figure 1) were homogeneous for all gram-positive pathogens (other data not shown) regardless of classification as cures or treatment failures. This finding strongly indicates that in vitro susceptibility testing to guide treatment decisions regarding the use of intramammary cephapirin is not useful.

\section{CONCLUSIONS}

Our study was not designed to evaluate the efficacy of intramammary treatment of gram-positive mastitis pathogens with cephapirin sodium and did not contain a negative control group. The overall cure rate of $82 \%$ reported by our study is greater than that reported by earlier studies and represents cures that are attributable to both treatment and spontaneous recovery. The low recurrence rate of mastitis in cured quarters suggests that the cure rates are not an overestimation. However, because of the lack of a control group, the cure rate attributable to spontaneous elimination of intramammary pathogens by the host immune system could not be determined.

The lack of association between MIC and bacteriological cure demonstrates that MIC is a poor predictor of bacteriological cure for IMI treated using cephapirin. Very few isolates exhibited in vitro resistance to cephapirin. Furthermore, no association was found between the results of susceptibility testing and bacteriological outcomes. Given the cost of antimicrobial susceptibility testing and its inability to accurately predict bacteriological outcomes of subclinical and clinical mastitis, it may be in the best economic interests of both dairy producers and veterinarians to not rely on the results of this test.

To better understand the mechanisms of drug-pathogen interaction at the udder level and to identify the role MIC could play in predicting bacteriological cure, further research is needed to compare in vitro MIC of the mastitis pathogens with in vivo cure at known concentrations of bacteria and quantified concentrations of the antimicrobials in the udder tissues.

\section{REFERENCES}

Apparao, D. J., L. Oliviera, and P. L. Ruegg. 2009. Relationship between in vitro susceptibility test results and treatment outcomes for gram-positive mastitis pathogens following treatment with pirlimycin hydrochloride. J. Am. Vet. Med. Assoc. in press.

Cattell, M. B., R. P. Dinsmore, A. P. Belschner, J. Carmen, and G. Goodell. 2001. Environmental gram-positive mastitis treatment: In vitro sensitivity and bacteriologic cure. J. Dairy Sci. 84:20362043.

Clinical Laboratory Standards Institute. 2007. Performance standards for antimicrobial disk and dilution susceptibility tests for bacteria isolated from animals. Approved standard, 3rd ed. CLSI document M31-A3. Clinical Laboratory Standards Institute, Wayne, PA.

Constable, P. D., and D. E. Morin. 2002. Use of antimicrobial susceptibility testing of bacterial pathogens isolated from the milk of dairy cows with clinical mastitis to predict response to treatment with cephapirin and oxytetracycline. J. Am. Vet. Med. Assoc. 221:103-108.

Constable, P. D., and D. E. Morin. 2003. Treatment of clinical mastitis: Using antimicrobial susceptibility profiles for treatment decisions. Pages 139-156 in The Veterinary Clinics of North America, Food Animal Practice, 19. W. B. Saunders, Philadelphia, PA.

Daley, M. J., G. Furda, R. Dougherty, P. A. Coyle, T. J. Williams, and P. Johnston. 1992. Potentiation of antibiotic therapy for bovine mastitis by recombinant bovine interleukin-2. J. Dairy Sci. 75:3330-3338.

Erskine, R. J., R. D. Walker, C. A. Bolin, B. C. Bartlett, and D. G. White. 2002. Trends in antibacterial susceptibility of mastitis pathogens during a seven-year period. J. Dairy Sci. 85:11111118.

Guterbock, W. M., A. L. Van Eenennaam, R. J. Anderson, I. A. Gardner, J. S. Cullor, and C. A. Holmberg. 1993. Efficacy of intramammary antibiotic therapy for treatment of clinical mastitis caused by environmental pathogens. J. Dairy Sci. 76:3437-3444. 
Hoe, F. G. H., and P. L. Ruegg. 2005. Relationship between antimicrobial susceptibility of clinical mastitis pathogens and treatment outcome in cows. J. Am. Vet. Med. Assoc. 227:1461-1468.

Lago, A., and K. Leslie, R. Dingwell, P. Ruegg, L. Timms, and S. Godden. 2006. Preliminary validation of an on-farm culture system. Pages 290-291 in Proc. 45th Annu. Mtg. National Mastitis Council, Tampa, FL. Natl. Mastitis Council, Verona, WI.

Makovec, J. A., and P. L. Ruegg. 2003. Antimicrobial resistance of bacteria isolated from dairy cow milk samples submitted for bacterial culture: 8,905 samples (1994-2001). J. Am. Vet. Med. Assoc. 222:1582-1589.

Martin, S. W., A. W. Meek, and P. Willeberg. 1987. Veterinary Epidemiology. Iowa State University Press, Ames.

National Mastitis Council. 1999. Laboratory and Field Handbook on Bovine Mastitis. W. D. Hoard and Sons, Fort Atkinson, WI.

Owens, W. E., C. H. Ray, J. L. Watts, and R. J. Yancey. 1997. Comparison of success of antibiotic therapy during lactation and results of antimicrobial susceptibility tests for bovine mastitis. J. Dairy Sci. 80:313-317.

Owens, W. E., and J. L. Watts. 1987. Effects of milk on activity of antimicrobics against Staphylococcus aureus isolated from bovine udders. J. Dairy Sci. 70:1946-1951.

Owens, W. E., Z. Y. Xiang, C. H. Ray, and S. C. Nickerson. 1990 Determination of milk and mammary tissue concentrations of ceftiofur after intramammary and intramuscular therapy. J. Dairy Sci. 73:3449-3456.

Pol, M., and P. L. Ruegg. 2007. Relationship between antimicrobial drug usage and antimicrobial susceptibility of gram-positive mastitis pathogens . J. Dairy Sci. 90:262-273.
Rosenberg, J. B., B. Love, and D. L. Patterson. 2002. Bacterial cure and somatic cell count response of dairy cows with a positive California mastitis test at calving to therapy with cephapirin sodium. Vet. Ther. 3:381-386.

Sandholm, M., L. Kaartinen, and S. Pyorala. 1990. Bovine mastitisWhy does antibiotic therapy not always work? An overview. J. Vet. Pharmacol. Ther. 13:248-260.

Sundlof, S. F., J. B. Kaneene, and R. Miller. 1995. National survey on veterinarian initiated drug use in lactating dairy cows. J. Am. Vet. Med. Assoc. 207:347-352.

Thornsberry, C.. J. K. Marler, J. L. Watts, and R. J. Yancey Jr. 1993. Activity of pirlimycin against pathogens from cows with mastitis and recommendations for disk diffusion test. Antimicrob. Agents Chemother. 37:1122-1126.

Timms, L. L., and L. H. Schultz. 1984. Mastitis therapy for cows with elevated somatic cell counts or clinical mastitis. J. Dairy Sci $67: 367-371$.

USDA. 2005. Part IV: Antimicrobial Use on U.S. Dairy Operations, 2002. USDA:APHIS:VS:CEAH, National Animal Health Monitoring System, Fort Collins, CO \#N430.0905. http://www. aphis.usda.gov/vs/ceah/ncahs/nahms/dairy/index.htm\#dairy02

Watts, J. L., and R. J. Yancey Jr. 1994. Identification of veterinary pathogens by use of commercial identification systems and new trends in antimicrobial susceptibility testing of veterinary pathogens. Clin. Microbiol. Rev. 7:346-356. 